\title{
IMPLEMENTASI KEPALA MADRASAH DALAM MENINGKATKAN MUTU SEKOLAH (STUDI KASUS PADA MAN 2 MODEL BANJARMASIN)
}

\author{
Muhammad Yuliansyah \\ Program Studi Bimbingan dan Konseling \\ Fakultas Keguruan dan Ilmu Pendidikan \\ Universitas Islam Kalimantan Muhammad Arsyad Al Banjari \\ m.yuliansyahy@yahoo.com/085102359191
}

\begin{abstract}
ABSTRAK
Dunia pendidikan dalam hal ini lembaga persekolahan diberi kewenangan untuk mengurus dirinya sendiri dan mengelola kegiatan pendidikan sesuai dengan kebutuhan masyarakat dan daerahnya masing-masing, untuk menyediakan sumber daya manusia yang produktif dan mempunyai kemampuan profesional dalam meningkatkan mutu pendidikan sebagai bagian yang tidak terpisahkan dari proses pembangunan sumber daya manusia yang harus dilakukan secara terencana dan terarah sehingga mampu menyiapkan bangsa Indonesia dalam memasuki era globalisasi dan era otonomi daerah yang penuh dengan tantangan. Dalam rangka menentukan mutu sumber daya manusia di sekolah dan untuk kepentingan bangsa di masa depan, kepala madrasah dan guru-guru merupakan penanggung jawab dan pelaksana pendidikan yang utama, yang secara langsung berhubungan dengan anak atau peserta didik. Seberapa jauh keberhasilan pendidikan di lembaga-lembaga pendidikan persekolahan khususnya di tingkat ibtidaiyah sampai madrasah aliyah dimana ketergantungan terhadap guru masih besar, sangat ditentukan oleh profesionalisme dan kompetensi para guru dalam mendidik dan mengajar. Kepala sekolah dan guru samasama berperan sebagai tenaga kependidikan yang secara terpadu harus saling bekerjasama dan berkoordinasi serta saling menunjang untuk kelancaran dan keberhasilan tugas-tugas pendidikan di sekolah.
\end{abstract}

Kata Kunci : Implementasi, Mutu Sekolah

\begin{abstract}
Education in the accumulated complex is an organization, character, leadership, learning and society. This study aims to analyze superior school-based leadership in learning organizations in the Integrated Paud Mawar Banjarbaru Utara, South Kalimantan. The research targets are educators and education staff at the Mawar Banjarbaru Foundation, Utara Kota Banjarbaru. Data collection is obtained through observation, documentation, and using instruments as monitoring and evaluation. The data analysis used a qualitative descriptive method. The results showed the need to conduct learning workshops for teachers in educational organizations at Paud Terpadu Mawar and develop leadership patterns in superior school-based learning in terms of fostering school administration management, coaching educators and education personnel in learning methods, coaching the potential of students, fulfilling learning support facilities. and school infrastructure, and a planned learning outcome assessment system.
\end{abstract}

Keywords: Implementation, School Quality 


\section{PENDAHULUAN}

Kemajuan ilmu pengetahuan teknologi dan komonikasi membawa kepada disrupsi, sehingga membawa dampak kepada suatu perubahan yang cepat, mengejutkan dan memuaskan seperti munculnya gojek, go-fod, go-car, dan disisilainnya juga telah berkembangnya big data. blanded learning. artipikal intelegensi. Kasal (2017: 141) dapat dijelaskan bahwa disrupsi terjadi dengan ciri-cirinya; ( $3 \mathrm{~S}$ ) suprase (perubahan mengejutkan), sudden shift (perubahan secara tiba-tiba), spedd (perubahan cepat).

Perubahan yang sangat dahsyat dan bergerak dinamis, organis perkembangan perubahannya dalam kehdidupan siswa di sekolah, di rumah dan di masyarakat, baik dalam berteman, berkelompok, bermain, berdiskusi dan belajar, berkarir serta berkomonikasi di era indusri 4.0 sekarang ini. Maka hal ini perlu diantisipasi agar siswa dalam kehidupan pribadi, social, belajar dan karirnya tidak melelahkan dan tidak terlidas oleh kemajuan perubahan tersebut.

Setiap orang punya masalah, ada yang ringan dan ada yang berat. Begitu pula cara mengatasi masalah yang dihadapi setiap orang ada yang dapat mengatasi masalahnya ada yang tidak. Ngalimun (2014:50) dapat dijelaskan bahwa tidak semua orang dapat mengatasi masalah. Bagi yang tidak mampu mengatasi masalah akan berakibat kepada terganggunya pikiraan, perasaan dan bahkan jiwanya. Maramis (2000:159) dapat dijelaskan bahwa masalah social dapat menyebabkan orang menjadi desprensif

Siswa di sekolah tentunya juga berbagai masalah yang dihadapi siswa baik masalah pribadi, social, belajar maupun karir. Masalah yang sering ditemui di sekolah, seperti terlambat Undang-Undang No. 20 tahun 2003 tentang Sistem Pendidikan Nasional Republik Indonesia, memberikan dasar hukum untuk mengembangkan pendidikan nasional dengan menerapkan prinsip demokrasi, desentralisasi, otonomi dan menjunjung tinggi hak-hak asasi manusia. Penerapan semua ketentuan dalam undang-undang ini diharapkan dapat mendukung segala upaya untuk memecahkan masalah pendidikan, yang pada gilirannya akan dapat memberikan sumbangan yang signifikan (meyakinkan) terhadap masalah makro bangsa Indonesia.

Selanjutnya di dalam undang-undang tersebut dikatakan bahwa sistem pendidikan nasional harus mampu menjamin pemerataan kesempatan pendidikan, peningkatan mutu serta relevansi dan efisiensi manajemen pendidikan untuk menghadapi tantangan sesuai dengan tuntutan perubahan kehidupan lokal, nasional dan global sehingga perlu dilakukan pembaharuan pendidikan secara terencana, terarah dan berkesinambungan untuk mencapai tujuan pendidikan.
Didalam undang-undang ini pasal I ayat I yang dimaksud dengan pendidikan adalah usaha sadar dan terencana untuk mewujudkan suasana belajar dan proses pembelajaran agar peserta didik secara aktif dapat mengembangkan potensi dirinya untuk memiliki kekuatan spiritual keagamaan, pengendalian diri, kepribadian, kecerdasan, akhlak mulia serta keterampilan yang diperlukan dirinya, masyarakat, bangsa dan negara.

Pada Bab II ayat 3 yang berkaitan dengan fungsi dan tujuan, dijelaskan bahwa pendidikan nasional berfungsi mengembangkan kemampuan dan membentuk watak serta peradaban bangsa yang bermartabat dalam rangka mencerdaskan kehidupan bangsa, bertujuan untuk berkembangnya potensi peserta didik agar menjadi manusia beriman dan bertaqwa terhadap Tuhan Yang Maha Esa, berakhlak mulia, sehat, berilmu, cakap, kreatif, mandiri dan menjadi warga negara yang demokratis serta bertanggung jawab. Begitu luhur dan mulianya bunyi rumusan tujuan pendidikan tersebut yang mampu mengantar bangsa ini menjadi bangsa yang terhormat dan bermartabat dan sejajar dengan bangsa-bangsa maju lainnya.

Namun jelas dipahami bahwa harapan yang indah, mulia ini tidak akan datang dengan sendirinya tanpa usaha yang keras dan nyata, karena untuk menuju ketujuan tersebut banyak tantangan yang harus dihadapi, baik yang datang dari dalam seperti malas, etos kerja rendah, kurang kreatif, dan pengaruh yang datang dari luar derasnya persaingan global.

Bersama dengan itu arus reformasi yang melanda kehidupan masyarakat dan bangsa sebagai salah satu dari gelombang reformasi total tersebut adalah lahirnya Undang-Undang No. 22 tahun 1999 tentang Pemerintahan Daerah dan Undang-undang No. 25 tahun 1999 tentang perimbangan keuangan pusat dan daerah. Kedua undang-undang tersebut merupakan undang-undang otonomi daerah yang berlaku efektif di seluruh Indonesia.

\section{METODE}

Pendekatan dalam Penelitian ini adalah menggunakan pendekatan kualitatif. Bogdan dan Taylor dalam Moleong (2000: 3) mendifinisikan metode kualitatf sebagai prosedur penelitian yang menghasilkan data deskriptif berupa kata-kata tertulis atau lisan dari orang-orang dan perilaku yang dapat diamati. Kirk dan Miller (1986: 9) Penelitian kualitatif adalah tradisi tertentu dalam ilmu pengetahuan sosial yang secara fundamental bergantung pada pengamatan manusia dalam kawasannya sendiri dan berhubungan dengan orang-orang tersebut dalam bahasanya dan dalam peristilahannya.. 
Pendekatan kualitatif mempunyai tujuan bahwa yang diteliti adalah sesuatu yang .penting (essensial) dan digunakan latar alami (Natural setting) sebagai sumber data langsung. Penelitian kualitatif mempunyai 5 sifat atau karakteristik: a. Latar alami b. Deskriptif c. Penonjolan proses, d. Analisis induksi, dan e, Pengungkapan makna (Bogdan dan Biklen 1982: 27).

\section{HASIL DAN PEMBAHASAN}

Berdasarkan analisis temuan yang ditemukan dalam penelitian ini diperoleh beberapa tema pokok yang akan dibahas dalam bab ini, yaitu:

1. Upaya Kepala Madrasah dalam pengelolaan proses belajar mengajar yang bermutu

2. Upaya Kepala Madrasah dalam mengkoordinasikan staf

3. Upaya kepala Madrasah dalam pengelolaan kesiswaan

4. Upaya Kepala Madrasah dalam pengelolaan sarana dan prasarana Madrasah

5. Upaya Kepala Madrasah dalam pengelolaan dana madrasah

6. Bentuk Kerjasama Madrasah dengan masyarakat

7. Upaya Kepala Madrasah dalam mengelola layanan khusus

Team teaching, model pembelajaran hendaknya membutuhkan variasi yang tidak menjenuhkan siswa. Adanya satu pelajaran diajarkan oleh dua atau tiga orang guru dalam satu kelas merupakan model pembelajaran yang variatif. Yang menjadi masalah adalah apakah sekolah mampu menyediakan guru yang cukup? Model ini juga membutuhkan koordinasi antar guru dalam menyampaikan materi jika tidak kompak akan menjadikan guru kurang dipercaya oleh siswa, namun juga dapat saling melengkapi kekurangan diantara guru terutama guru honor dan guru yang baru diangkat dan di tugaskan di MAN 2 Banjarmasin, serta team teaching yang memberikan bimbingan dan pembelajaran kepada siswa yang akan mengikuti lomba akademik.

Kepala MAN 2 Model Banjarmasin juga memberikan kesejahteraan bagi guru-guru dan karyawan berupa tunjangan hari raya, baju dinas kerja, pembagian SHU setiap akhir tahun pertangungjawaban koperasi, dan kesejahteraan lainnya sesuai kemampuan keuangan yang ada di Komite Sekolah.

Begitu juga hasil kelulusan MAN 2 Model Banjarmasin yang diterima di berbagai perguruan tinggi negeri maupun swasta baik melalui PMDK ataupun melalui jalur tes, yang diterima di Polri dan bekerja di Instansi pemerintah maupun swasta. Ini merupakan out put dari hasil pendidikan yang mereka terima dari MAN 2 Model Banjarmasin

\section{KESIMPULAN}

Berdasarkan hasil penelitian dan analisisnya didapati kesimpulan bahwa:

Kepemimpinan kepala sekolah dalam meningkatkan mutu pendidikan di man 2 model memegang prinsip kepemimpinan demokratis. Segala,upaya dan usaha yang beliau lakukan selalu melibatkan pihak-pihak lain sehingga keputusan yang terbaik dapat diambil dengan tidak mengesampinkan kepentingan bersama. Rapat pertemuan dan evaluasi terus dilakukan demi menghindari meminimalisir kendala yang terjadi didalam proses pelaksanaan peningkatan mutu pendidikan.

Kendala yang sering muncul ketika peningkatan mutu pendidikan yang dipimpin kepala sekolah adalah masalah kurang sadar dari siswa dan orang tua siswa akan arti pentingnya suatu pendidikan yang bermutu, lembaga pemerintahan atau instansi pendidikan lain yang kurang mendukung, kurikulum yang sering berubah-ubah samapai pada keberadaan dua lokasi sekolah yang menyulitkan kepala sekolah dalam melaksanakan peningkatan mutu pendidikan.

Segala upaya dilakukan oleh kepala sekolah demi meminimalisir kendala yang muncul yaitu dengan mengadakan pertemuan dengan siswa dan orangtua siswa untuk bersama-sama menjelaskan dan mempresentasikan program yang akan dilaksankan sehingga respon positif dari mereka dapat mendukung keberhasilan peningkatan mutu pendidikan. Mengadakan pertemuan at

au mengikuti rapat rutin dengan pihak-pihak lembaga pendidikan sehingga dukungan dan bantuan dapat diperoleh dengan mudah.

Berdasarkan hasil penelitian yang dilakukan telah banyak memberikan informasi dan masukanmasukan yang positif untuk menambah khasanah keilmuan khususnya dalam bidang pendidikan. Untuk itu peneliti mencoba memberikan saran agar penelitian selanjutnya dapat berjalan lebih baik dan dapat menjadi masukan-masukan bagi pihak Madrasah Aliyah Negeri untuk terus mengevaluasi kesalahan dan kekurangan yang ada.

\section{DAFTAR PUSTAKA}

Arcaro, Jerome, S. Quality in Education (Delray Beach, Florida, ST.Lucie Press, 1995)

Arikunto Suharsimi, Manajemen Pengajaran Manusiawi (Jakarta: Rineka Cipta, 1990).

Atmodiwirio, Soebagio, Manajemen Pendidikan di Indonesia, (Jakarta: Ardadizya, 2003) 
Bogdan, R.C, \& Biklen, Qualitative Research For Gozali Ahmad, Dkk. Kepemimpinan kepala Madrasah Education an Introductionto theory and Methods (Boston: Allyn \& Bacon Inc 1982) yang efektif, (Jakarta, Badan Litbang Agama dan Diklat Keagamaan Pusdiklat Administrasi, 2004)

Departemen Agama RI, Manajemen Madrasah, (Jakarta: Handayaningrat, Soewarno, Pengantar Studi direktorat Jenderal Kelembagaan Agama Islam, Administrasi dan Manajemen, (Jakarta: Haji 2001). Masagung, 1988)

Departemen Agama RI, Pedoman Kurikulum Madrasah Hornby, A.S. Dictionary Of Current English (Oxford Aliyah Berciri Khas agama Islam, (Jakarta: direktorat Jenderal Kelembagaan Agama Islam, 1998/1999).

Departemen Agama RI, Desain Pengembangan Madrasah, (Jakarta: direktorat Kelembagaan Agama Islam, 2004). University Press 1982)

Kamaruddin, Drs, Ensiklopedi Manajemen, (Bandung: Alumni, 1979)

Lembaga Pendidikan dan Pembinaan Manajemen, Kamus Istilah Manajemen, (Jakarta: Balai Aksara, 1983).

Departemen Agama RI, Pedoman Manajemen Berbasis Manca, W, Etnografi Desain Penelitian Kualitatif, dan Madrasah, (Jakarta: Direktorat Jenderal Manajemen Pendidikan, (Malang: Wineka Kelembagaan agama Islam, 2003) Media, 2004).

Departemen Agama RI, Pedoman Standar Madrasah Moekijat, Drs, Kamus Manajemen, (Bandung: Alumni, Aliyah, (Jakarta:Direktorat Kelembagaan Agama Islam, 2005).

Departemen Agama RI, Profil Madrasah Aliyah,( Jakarta: Direktorat Jenderal Kelembagaan Agama Islam, 2005). 1980).

Moleong, L.J. Metode Penelitian kualitatif, (Bandung: Ramaja Resdakarya, 2000).

Mulyasa, E, Manajemen Berbasis Sekolah, (Bandung: Remaja Resdakarya,2003).

Departemen Agama RI, Sejarah Madrasah Pertumbuhan, Dinamika dan Perkembangannya Mulyasa,E, Menjadi Kepala Sekolah Profesional, di Indonesia, (Jakarta: Direktorat kelembagaan Agama Islam, 2004)

Departemen Agama RI, Sejarah Perkembangan (Bandung: Remaja Rosdakarya, 2005).

Nasution, S, Metode Penelitian Naturalistik - Kualitatif, (Bandung: Tarsito, 1998). Madrasah, (Jakarta: Diraktorat Kelembagaan agama Islam, 1998/1999).

Nawawi, H, Organisasi Sekolah dan Pengelolaan Kelas sebagai lembaga Pendidikan, ( Jakarta: Gunung Agung, 1982).

Departemen agama RI, Himpunan Perundangundangan Tentang Pendidikan Nasional Perguruan Agama Islam, (Jakarta: direktorat Purwadarminta, W.J.S. Kamus Umum Bahasa Kelembagaan Agama Islam, 1998/1999). Indonesia,(Jakarta: Balai Pustaka, 1996)

Sahertian, P.A. Profil Pendidikan Nasional, (Yogyakarta: Andi Offset, 1994)

Departemen Pendidikan dan Kebudayaan RI, Kamus Besar Bahasa Indonesia, (Jakarta: Balai Pustaka, 1989)

Djamas, Nurhayati, Dr, MA, Manajemen madrasah Mandiri, (Jakarta: Puslitbang Pendidikan agama Sarwoto, Dasar-Dasar Organisasi dan Manajemen, dan Keagamaan Badan Litbang Agama dan Diklat Keagamaan, 2005)

Fattah, Nanang, Landasan Manajemen Pendidikan, (Bandung; Remaja Resdakarya, 2000).

Sallis,E. Total Quality Management in Educatiol, (London: Kongan Page Educational Management Series 1993)

(Jakarta: Ghalia Indonesia, 1986).

Shargel, F.P Transforming Educational Through Total Quality Management, (new York: Eye on Educational 1993) 
Soetopo, Hendyat, dan Wasty Soemanto, Pengantar Operasional Administrasi Pendidikan, (Surabaya: Usaha Nasional, 1983)

Sonhaji, Ahmad, Metode Penelitian Kualitatif Dalam Pendidikan, (Banjarmasin: Universitas Lambung Mangkurat, Program S2 Manajemen Pendidikan, 2003).

Sukmadinata, Nana Syaodih, Pengembangan Kurikulum, (Bandung: Remaja Rosdakarya, 1977)

Sukmadinata, Nana Syaodih, et al, Pengendalian Mutu Pendidikan Sekolah Menengah, (Bandung: Refika Aditama, 2006)

Sutarto, Dasar- Dasar Organisasi (Yogyakarta: Gajah Mada University Press, 1992).

Sutisna, O. Administrasi Pendidikan: Dasar Teoritis Untuk Praktek Profesional, (Bandung: Angkasa 1985 ).

Terry, G.R, Principles Of Management, (Homewood Illinois: Rivhard D.Irwin, 1972)

Tilar, H.A.R, Manajemen Pendidikan Nasional, Kajian Pendidikan Masa Depan, (Bandung, Resdakarya 1994)

Tjiptono, F. dan Diana, A.Total Quality Management (Yogyakarta: Andi Offset, 1995)

.Undang- Undang Nomor 20 Tahun 2003 Tentang Sistem Pendidikan Nasional, (Bandung: Citra Umbara, 2003)

Wahjosumijo, Kepemimpinan Kepala Sekolah, (Jakarta: Raja Grafindo Persada, 2003)

Yahya, M, Metodologi Penelitian,Riset dan teori, (Banjarmasin: STIA Bina Banua, 2004).

Yulk.G Leadership in Organization, (Jakarta:Alih Bahasa Udaya 1998) 